\title{
Anti-Inflammatory Effects of Ginsenoside Rg3 via NF- $\kappa$ B Pathway in A549 Cells and Human Asthmatic Lung Tissue
}

\author{
In-Seung Lee, ${ }^{1,2}$ InJoon Uh, ${ }^{2,3}$ Ki-Suk Kim, ${ }^{1}$ Kang-Hoon Kim, ${ }^{1,2}$ Jiyoung Park, ${ }^{1,2}$ \\ Yumi Kim, ${ }^{1,2}$ Ji-Hoon Jung, ${ }^{1}$ Hee-Jae Jung, ${ }^{2,3}$ and Hyeung-Jin Jang ${ }^{1,2,3}$ \\ ${ }^{1}$ College of Korean Medicine, Kyung Hee University, 26, Kyungheedae-ro, Dongdaemun-gu, Seoul 02447, Republic of Korea \\ ${ }^{2}$ Department of Science in Korean Medicine, Graduate School, Kyung Hee University, Seoul, Republic of Korea \\ ${ }^{3}$ Department of Biological Sciences in Korean Medicine, Graduate School, Kyung Hee University, Seoul, Republic of Korea \\ Correspondence should be addressed to Hyeung-Jin Jang; hjjang@khu.ac.kr
}

Received 13 September 2016; Revised 4 November 2016; Accepted 4 December 2016

Academic Editor: Andréia M. Cardoso

Copyright (C) 2016 In-Seung Lee et al. This is an open access article distributed under the Creative Commons Attribution License, which permits unrestricted use, distribution, and reproduction in any medium, provided the original work is properly cited.

\begin{abstract}
Objective. There is limited information of the anti-inflammatory effects of $\operatorname{Rg} 3$ on inflamed lung cells and tissues. Therefore, we confirmed the anti-inflammatory mechanism of ginsenoside Rg3 in inflamed human airway epithelial cells (A549) and tissues whether Rg3 regulates nuclear factor kappa B (NF- $\kappa \mathrm{B})$ activity. Methods. To induce the inflammation, IL- $1 \beta(10 \mathrm{ng} / \mathrm{ml}) \mathrm{was}$ treated to A549 cells for $4 \mathrm{~h}$. The effects of Rg3 on NF- $\kappa \mathrm{B}$ activity and COX-2 expression were evaluated by western blotting analysis in both IL-1 $\beta$-induced inflamed A549 cell and human asthmatic airway epithelial tissues. Using multiplex cytokines assay, the secretion levels of NF- $\kappa \mathrm{B}$-mediated cytokines/chemokines were measured. Result. Rg3 showed the significant inhibition of NF$\kappa \mathrm{B}$ activity thereby reduced COX-2 expression was determined in both IL-1 $\beta$-induced inflamed A549 cell and human asthmatic airway epithelial tissues. In addition, among NF- $\kappa$ B-mediated cytokines, the secretion levels of IL- 4 , TNF- $\alpha$, and eotaxin were significantly decreased by Rg3 in asthma tissues. Even though there was no significant difference, IL-6, IL-9, and IL-13 secretion showed a lower tendency compared to saline-treated human asthmatic airway epithelial tissues. Conclusion. The results from this study demonstrate the potential of $\mathrm{Rg} 3$ as an anti-inflammatory agent through regulating NF- $\kappa \mathrm{B}$ activity and reducing the secretion of NF- $\kappa$ B-mediated cytokines/chemokines.
\end{abstract}

\section{Introduction}

Asthma is an inflammatory disease which affects the airway of the lungs [1]. The repeated hysterical symptoms such as swell and narrow, leading to wheezing, limited breath, chest tightness, and coughing, are typical characters [2, 3]. It has become one of the most common health problems and a huge onus on healthcare costs worldwide [4]. The World Health Organization (WHO) has announced there was a sharp increase in the number of cases of asthma since the 1970s and the rates of increase show no signs of slowing. The exact cause of asthma has not been determined but studies have suggested that asthma resulted from a complex combination of genetic factors and environmental factors [5]. Ober and Hoffjan have been studying the genetic factors of asthma and they reported that over 100 genes were associated with asthma [6]. Many studies have proved there are two main factors of causing asthma: cause substance and deterioration factor. Cause substance, called allergen, is known to be dust mites, cockroaches, animal dander, and mold. The other type, deterioration factors, is air pollution, smoking, low air condition, climate change, stress, and yellow sand phenomenon $[7,8]$. Allergic asthma, ordinarily related to atopy, is the most common type of asthma [9]. It is characterized by a reversible obstruction of the peripheral airway, induced by airway hyperresponsiveness (AHR), and infiltration of inflammation into the lung parenchyma $[10,11]$. Atopy, the powerful risk factor of allergic asthma, is abnormally increased status of immunoglobulin E (IgE) which responds to allergen such as mold, animal, fur, and dust mites [12,13]. Atopy is also involved in inflammation-related diseases such as allergic rhinitis, conjunctivitis, and atopic dermatitis [14].

The crucial role of type 2 helper cells (Th2 cells) immune pathway elements in AHR has been identified [15]. The effect 
of Th2 cells in inflammatory reaction of allergic asthma has been pointed out in several studies [16-18]. The antigenpresenting dendritic cells recognize allergen and active Th2 cells to stimulate the secretion level of cytokines including interleukin- (IL-) 4, 5, 9, and 13 and tumor necrosis factoralpha (TNF- $\alpha$ ) [11, 19-21]. IL-4 is known to lead Th2 cells differentiation. The function of IL-13 is similar to IL-4 [20]. Both IL- 4 and IL-13 participate in alteration of IgE status in $B$ cells $[16,17]$. IL- 5 causes the differentiation of eosinophils which leads to the release of proinflammatory mediators and reactive oxygen species (ROS) [22]. On the contrary, type 1 helper cells (Th1 cells) secrete interferon gamma (IFN- $\gamma$ ), IL2 , and IL-12, and those cytokines inhibit Th2 cells activation $[23,24]$. Therefore, the main target of the treatment of allergic asthma is inhibiting Th2 cells-associated cytokines, IL-4, IL5, and IL-13, or promoting Th1 cells-associated cytokines.

In response to innate and adaptive immune response regulating the release of cytokines through allergic asthma, nuclear factor kappa-light-chain-enhancer of activated B (NF- $\kappa \mathrm{B})$ cells has been known to be involved in an activation of distinct signaling component through a cascade of phosphorylation [25]. NF- $\kappa \mathrm{B}$, a protein complex, acts as a key role in regulating the immune response to infection $[26,27]$. Because it regulates many genes involved in inflammation with several studies proved that NF- $\kappa \mathrm{B}$ is highly activated at sites of inflammation in various human diseases such as rheumatoid arthritis, atherosclerosis, multiple sclerosis, and asthma and also in the murine model $[15,28,29]$. When NF$\kappa \mathrm{B}$ is activated, the combined form of p50 and p65 enters the nucleus and then p50 and p65 subunits bind with DNA thereby causing the expression of various gene products such as nitric oxide (NO), cyclooxygensase-2 (COX-2), and tumor necrosis factor-alpha (TNF- $\alpha$ ) [30]. The former studies have proven that it is functionally related to the development of allergic disease of the airways by using mice that lacked p50 or c-Rel subunits of NF- $\kappa \mathrm{B}[31,32]$.

Korean medicine has been interested in treatment modality among allergic disease patients [33]. Also, herbal medicines and its extracts have prescribed as an antiinflammatory agent in clinical study [34]. Although herbal medicines have been known as the medicinal with antiallergic effects in clinical study, it was hard to find what component affected the anti-inflammation and regulated innate or adaptive immune response [33, 35]. Red ginseng (RG, derived from a steamed root of Panax ginseng Meyer) was chosen in this study, because the RG has been steadily used as a Korean medicine in clinical prescription and the anti-inflammatory effects in several studies have been researched [36-39]. Ginsenosides, so-called major component of Saponins, are the major component of RG [40]. Other studies have identified more than 40 ginsenosides in RG and most ginsenosides demonstrate various biological properties such as anti-inflammatory, antiallergic, and antitumor effects [41-43]. Various studies have reported that ginsenosides have an antiallergic effect on murine asthma and atopic disease models and among the ginsenosides $\mathrm{Rh} 1$ and $\mathrm{Rh} 2$ have antiallergic and anti-inflammatory effects [44, 45]. Ginsenoside Rg3 (Rg3) is the main component of RG [46]. Many studies have reported that $\mathrm{Rg} 3$ has an anti-inflammatory effect by reducing COX-2, inducible nitric oxide synthase (iNOS), and proinflammatory cytokines, including TNF- $\alpha$ and IL-1 $\beta$ expression, induced by LPS stimulation in vitro [47-49]. However, there is no study of the effects of Rg3 on human inflammation induced airway epithelial cells and human asthmatic airway epithelial tissue. Here, we examined how $\mathrm{Rg} 3$ affects the inflammatory reaction in IL-1 $\beta$-induced inflamed human epithelial cells and human asthmatic airway epithelial tissue. And we demonstrated that $\mathrm{Rg} 3$ on activating condition of NF- $\kappa \mathrm{B}$ suppressed the proinflammatory cytokines secretion on human airway epithelial tissue.

\section{Material and Methods}

2.1. Materials. Rg3 and dexamethasone (Dex) were obtained from Sigma-Aldrich (St. Louis, MO, USA). Interleukin-1 beta (IL-1 $\beta$ ) was obtained from R\&D system Inc. (Minneapolis, MN, USA). Rabbit anti-phospho-NF- $\kappa$ B p65, antiNF- $\kappa$ B p 65 , and anti-COX-2 were purchased from Cell Signaling Tech (Beverley, MA, USA). Mouse anti- $\beta$-actin, goat anti-rabbit IgG-HRP, and goat anti-mouse IgG-HRP were purchased from Santa Cruz Biotechnology (Dallas, TX, USA). Assay Media Sterile was purchased from MatTek Corp. (Ashland, MA, USA). Human Cytokine 6-plex Flat Bottom Express (TNF- $\alpha$, eotaxin, IL-4, IL-5, IL-9, and IL13) and protein assay reagent were purchased from BioRad (Hercules, CA, USA). Protease inhibitor cocktail was obtained from Roche Diagnostics (Mannheim, Germany).

2.2. Cell Line and Culture Condition. A549 cells (American Type Culture Collection, Rockville, MD, USA), human airway epithelial cells, were used in all in vitro studies. The cells were cultured in RPMI 1640 medium (Corning Inc., NY, USA) containing 10\% FBS (Gibco, Grand Island, NY, USA) and antibiotic and antimycotic (ABAM; Corning Inc., NY, USA) and incubated at $37^{\circ} \mathrm{C}$ and $5 \% \mathrm{CO}_{2}$. Overnight serum starvation using Dulbecco's Modified Eagle Medium (DMEM: Corning Inc., NY, USA) containing low glucose without FBS was performed before IL-1 $\beta$-induced inflammation at $37^{\circ} \mathrm{C}$ and $5 \% \mathrm{CO}_{2}$.

2.3. Cell Viability Assay. MTT assays were performed to evaluate the cytotoxicity of $\operatorname{Rg} 3$ on inflamed cells. Ten thousands of A549 cells cultured each well of 96-well plate and were incubated at $37^{\circ} \mathrm{C}$ and $5 \% \mathrm{CO}_{2}$ overnight. After serum starvation using DMEM low glucose without FBS, the medium was changed into RPMI containing IL- $1 \beta(10 \mathrm{ng} / \mathrm{ml})$ and the cells were incubated at $37^{\circ} \mathrm{C}$ and $5 \% \mathrm{CO}_{2}$ for $4 \mathrm{~h}$. After $4 \mathrm{~h}$ incubation, the cells were treated with $\mathrm{Rg} 3(100-900 \mathrm{nM})$ for $12 \mathrm{~h}$. Thirty microliters of MTT solution $(5 \mathrm{mg} / \mathrm{ml})$ was added to each well and the cells were incubated for $2 \mathrm{~h}$. After $2 \mathrm{~h}$ incubation in cell culture incubator, the medium containing MTT solution of each well was removed and $50 \mu \mathrm{l}$ of dimethyl sulfoxide (DMSO; Sigma-Aldrich, MO, USA) was added. Using an automated spectrophotometric plate reader at $570 \mathrm{~nm}$, the optical density of formazan was measured. 
TABLE 1: Description of asthmatic human airway epithelial tissue donors.

\begin{tabular}{|c|c|c|c|c|c|c|}
\hline Age & Sex & Race & Smoking & Disease & Cause of death & Medication \\
\hline 7 & $\mathrm{~F}$ & $\mathrm{C}$ & $\mathrm{N}$ & Asthma & & Albuterol \\
\hline 9 & $\mathrm{~F}$ & B & $\mathrm{N}$ & Asthma since birth & Possible asthma attack & Albuterol \\
\hline 16 & M & B & $\mathrm{N}$ & Asthma & & Advair \\
\hline
\end{tabular}

M, male; F, female; C, Caucasian; B, black; N, none.

2.4. Human Asthmatic Airway Epithelial Tissue Culture. Asthmatic primary differentiated human airway epithelial tissues grown in 24-well plates on collagen coated transwell membrane inserts at an air-liquid interface were obtained commercially from MatTek Corporation (MatTek Corp., Ashland, MA, USA). Donors' information of asthmatic airway epithelial tissues is shown in Table 1. On arrival, the ex vivo epithelial tissues were washed with Dulbecco's Phosphate Buffered Saline (D-PBS) for removing collagen coating and carefully moved to 6-well plates that added $1 \mathrm{ml}$ of Assay Media Sterile (AIR-100-ASY; MatTek Corp., Ashland, MA, USA) per each well. Tissues were equilibrated at $37^{\circ} \mathrm{C}$ and $5 \%$ $\mathrm{CO}_{2}$ for $16 \mathrm{~h}$. After equilibration, the tissues were treated with saline, $1 \mu \mathrm{M}$ of Dex (Sigma-Aldrich, St. Louis, MO, USA), or $50 \mu \mathrm{M}$ of $\mathrm{Rg} 3$ for $24 \mathrm{~h}$ at $37^{\circ} \mathrm{C}$ and $5 \% \mathrm{CO}_{2}$.

2.5. Western Blot Analysis. For the in vitro study, A549 cells were seeded in 6 -well plate $\left(5 \times 10^{5}\right.$ cells/well $)$ and incubated at $37^{\circ} \mathrm{C}$ and $5 \% \mathrm{CO}_{2}$ overnight. After serum starvation and inflammation induction using IL- $1 \beta(10 \mathrm{ng} / \mathrm{ml})$, the cells were treated with Dex $(5 \mu \mathrm{M})$ or $\operatorname{Rg} 3(900 \mathrm{nM})$ for $12 \mathrm{~h}$. After each drug treatment for $12 \mathrm{~h}$, the cells were lysed by cell lysis buffer (Cell Signaling Tech., Beverley, MA, USA). The tissues were homogenized using the pestle. Each sample lysate from cell or tissue was centrifuged at $12,000 \mathrm{rpm}$ for $20 \mathrm{~min}$ at $4^{\circ} \mathrm{C}$. Supernatants were collected and transferred to fresh tube. Bio-Rad protein assay reagent (Bio-Rad, Hercules, CA, USA) was used for measuring protein concentrations. Each sample was separated on a $10 \%$ SDS-PAGE gel at $120 \mathrm{~V}$ for $120 \mathrm{~min}$ and then electrotransferred to a NC membrane for $100 \mathrm{~min}$ at $25 \mathrm{~V}$. The membranes were blocked with 5\% BSA in TBST (Tris-buffered saline with $0.1 \%$ Tween 20 and $0.04 \% \mathrm{NaN}_{3}$ ). Primary antibodies, that is, rabbit anti-phospho-NF- $\kappa \mathrm{B}$ p65, rabbit anti-NF- $\kappa \mathrm{B}$ p65, rabbit anti-COX-2, and mouse anti- $\beta$ actin, were stained onto the membrane in 1:1,000 dilutions (anti- $\beta$-actin was 1:3,000 dilution) for overnight. Membranes were extensively washed and then incubated with the following secondary antibodies: goat anti-rabbit IgG-HRP and goat anti-mouse IgG-HRP. Bands were visualized with an enhanced chemiluminescence (ECL) kit (EMD Millipore Co., Billerica, MA, USA) and were quantified with the Image J program (National Institutes of Health, Bethesda, MD, USA).

2.6. Analysis of Proinflammatory Cytokines in Human Asthmatic Airway Epithelial Tissues. After indicated drugs treatment for $24 \mathrm{~h}$ on human asthmatic airway epithelial tissues, each medium was collected and centrifuged at $1,000 \times \mathrm{g}$ for $10 \mathrm{~min}$. The centrifuged supernatant was transferred to fresh tubes. Human Cytokine 6-plex Flat Bottom Express (TNF$\alpha$, eotaxin, IL-4, IL-5, IL-9, and IL-13; Bio-Rad, Hercules, CA, USA) assay was performed according to the manufacturer's guidelines. Briefly, $50 \mu \mathrm{l}$ of centrifuged samples was transferred to each well that included human cytokine 6-plex magnetic beads: IL-4, IL-5, IL-9, IL-13, TNF- $\alpha$, and eotaxin. The plate was incubated on shaker at $850 \mathrm{rpm}$ for $30 \mathrm{~min}$ at room temperature (RT). After $30 \mathrm{~min}$ of shaking incubation, the solution of each well was removed and changed into $25 \mu \mathrm{l}$ of detection antibody mixed solution and incubated on shaker at $850 \mathrm{rpm}$ for $30 \mathrm{~min}$ at RT. During $30 \mathrm{~min}$ incubation, streptavidin-PE (SA-PE) was diluted to assay buffer (Cat. number 10014822, Bio-Rad, Hercules, CA, USA), and then $50 \mu \mathrm{l}$ of SA-PE diluted solution was shifted to wells. Finally, $125 \mu \mathrm{l}$ of assay buffer was added to each well and measured by a Bio-Plex ${ }^{\circledR}$ MAGPIX ${ }^{\mathrm{TM}}$ Multiplex reader (BioRad, Hercules, CA, USA).

2.7. Statistical Analysis. Data were represented with the means \pm SEM. The GraphPad Prism 5 software package (GraphPad Software, San Diego, CA, USA) was used to conduct the statistical analysis of the results. Unpaired $t$ test (one-tailed) was conducted to analyze western blot band and multiplex assay results. $P$ value less than 0.05 was considered to be statistically significant.

\section{Results}

3.1. Effects of Rg3 on Cell Viability. To examine the cytotoxicity of Rg3 on IL-1 $\beta$-induced inflamed A549 cells, the cells were firstly treated with IL- $1 \beta(10 \mathrm{ng} / \mathrm{ml})$ for $4 \mathrm{~h}$ and treated with 100 to $900 \mathrm{ng} / \mathrm{ml}$ concentration of Rg3 for $12 \mathrm{~h}$. Cell viability was analyzed using an MTT assay. There was no observed cytotoxicity of Rg3 in IL-1 $\beta$-induced inflamed A549 cells compared to only PBS-treated cells (Con) (Figure 1).

3.2. Inhibition of IL-1 $\beta$-Stimulated NF- $\kappa B$ Expression by Rg3 in Inflamed A549 Cells. To obtain the anti-inflammatory effects of Rg3 on inflammation induced human lung epithelial cells, A549 cells inflammation was induced by IL- $1 \beta(10 \mathrm{ng} / \mathrm{ml})$ and then treated by $5 \mu \mathrm{M}$ of Dex or $900 \mathrm{nM}$ of Rg3. The NF- $\kappa \mathrm{B}$ activation was analyzed by a western blot analysis to evaluate the effect of Rg3 treatment on A549 cells (Figure 2(a)). The NF- $\kappa \mathrm{B}$ pathway plays a central role in immune and inflammatory responses, because the nuclear translocation of the NF- $\kappa \mathrm{B}$ p65 subunit stimulates the transcription of various proinflammatory genes. Phospho-NF- $\kappa \mathrm{B}$ p65/total NF- $\kappa$ B p 65 densitometry in the cells treated with Rg3 showed the significant decrease compared to IL-1 $\beta$-induced inflamed 


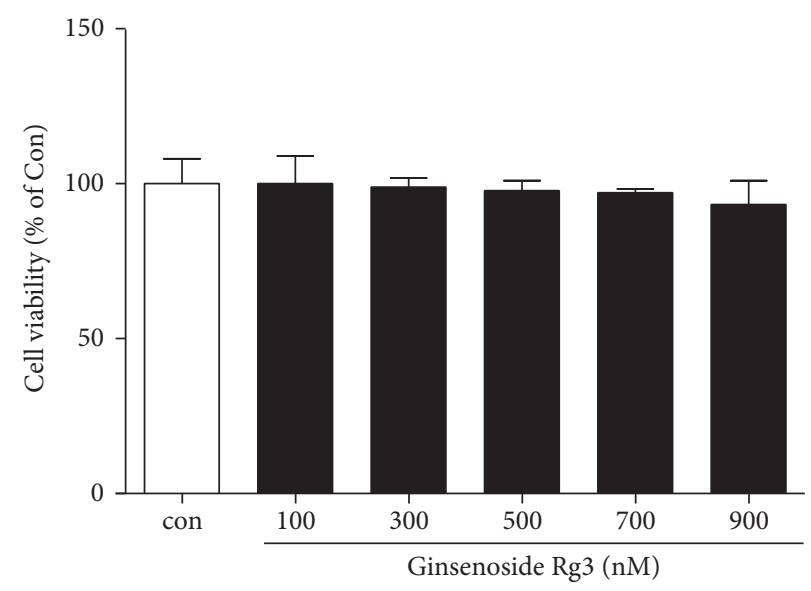

FIGURE 1: Cell viability assay of Rg3 on IL-1 $\beta$-induced inflamed A549 cells. After treatment of IL- $1 \beta$ ( $10 \mathrm{ng} / \mathrm{ml})$ and Rg3 (100-900 nM) on the A549 cells, MTT assay was performed. The cytotoxicity of Rg3 on IL- $\beta$-induced inflamed A549 cells was not detected. Statistical significance was determined by unpaired $t$ test (one-tailed) compared to Con (only treated PBS).
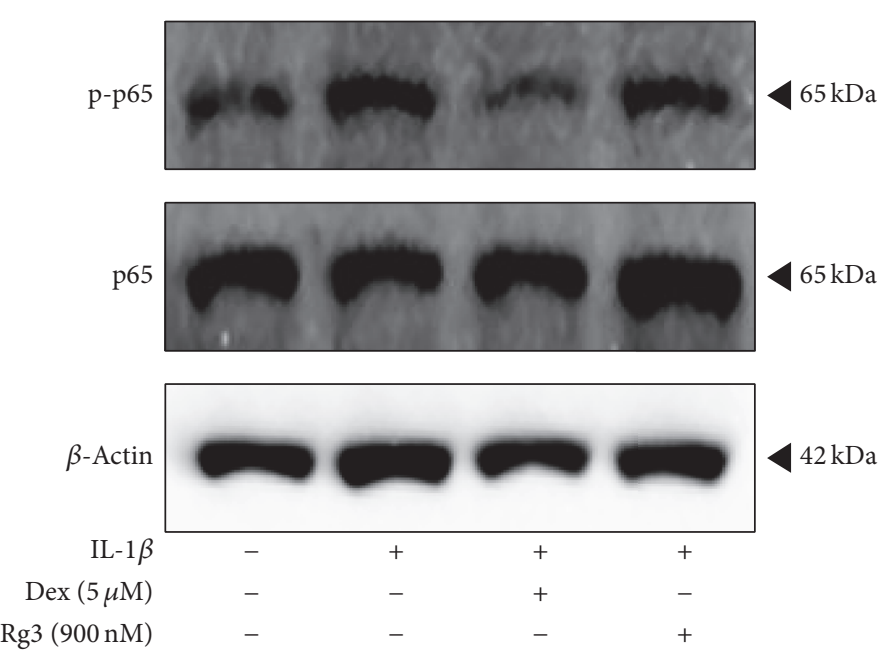

(a)

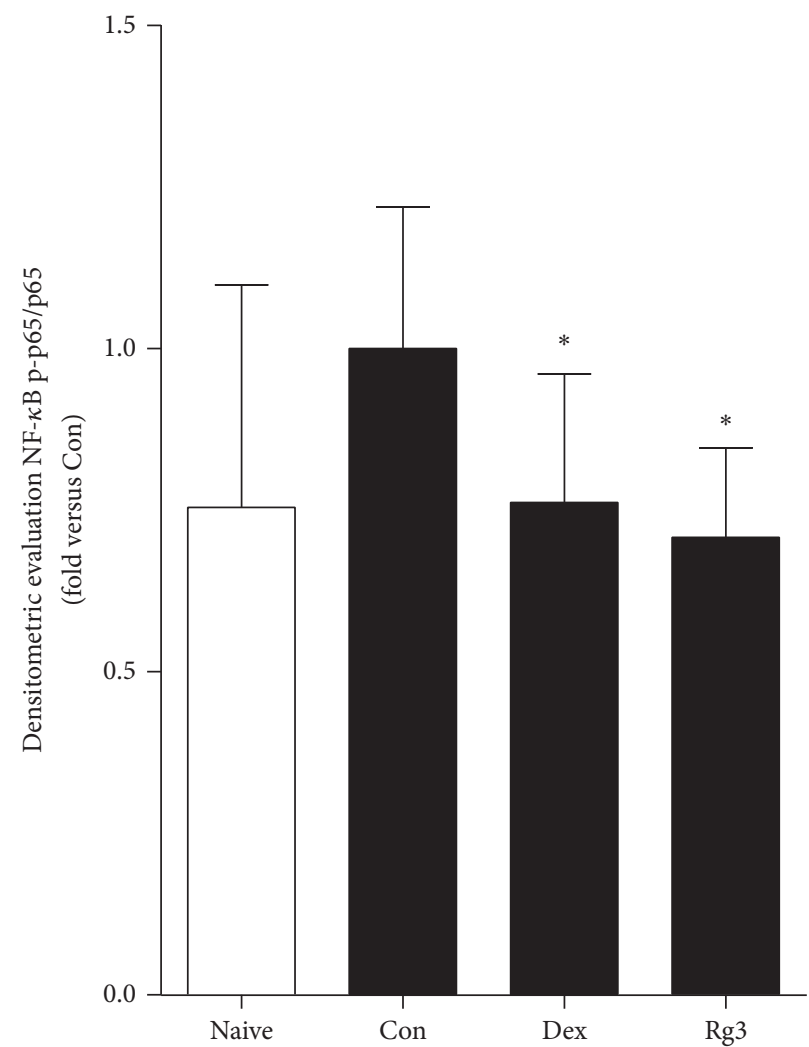

(b)

Figure 2: Effects of Rg3 on NF- $\kappa$ B pathway in IL-1 $\beta$-induced inflamed A549 cells. (a) The western blot results in representative three separate experiments. (b) Ratio of phospho-p65/p65 expression was measured by Image J program. Statistical significance was determined by unpaired $t$-test (one-tail) compared to Con. Values are means \pm SEM. ${ }^{*} P<0.05$. Naive: normal condition; Con: IL- $1 \beta$ treated A549 cells.

A549 cells (Figure 2(b)). The meaning of reducing the ratio of p-p65/p65 by Rg3 treatment is associated with NF- $\kappa$ B activation; thereby inflammation may be reduced.

3.3. Suppression Effects of Rg3 on COX-2 Protein Expression in IL-1 $\beta$-Induced Inflamed A549 Cells. As we examined whether Rg3 suppresses expression of a downstream mediator of
NF- $\kappa \mathrm{B}$ activation, we investigated COX-2 expression, known to be a downstream mediator of NF- $\kappa \mathrm{B}$ activation. COX2 is the enzyme that makes prostaglandins which arouse inflammation, pain, and fever. Thereby, we also investigated the expression of COX-2 in IL- $1 \beta$-induced inflamed A549 cells. We found that $\mathrm{Rg} 3$ downregulated the expression of COX-2 effectively (Figure 3). 


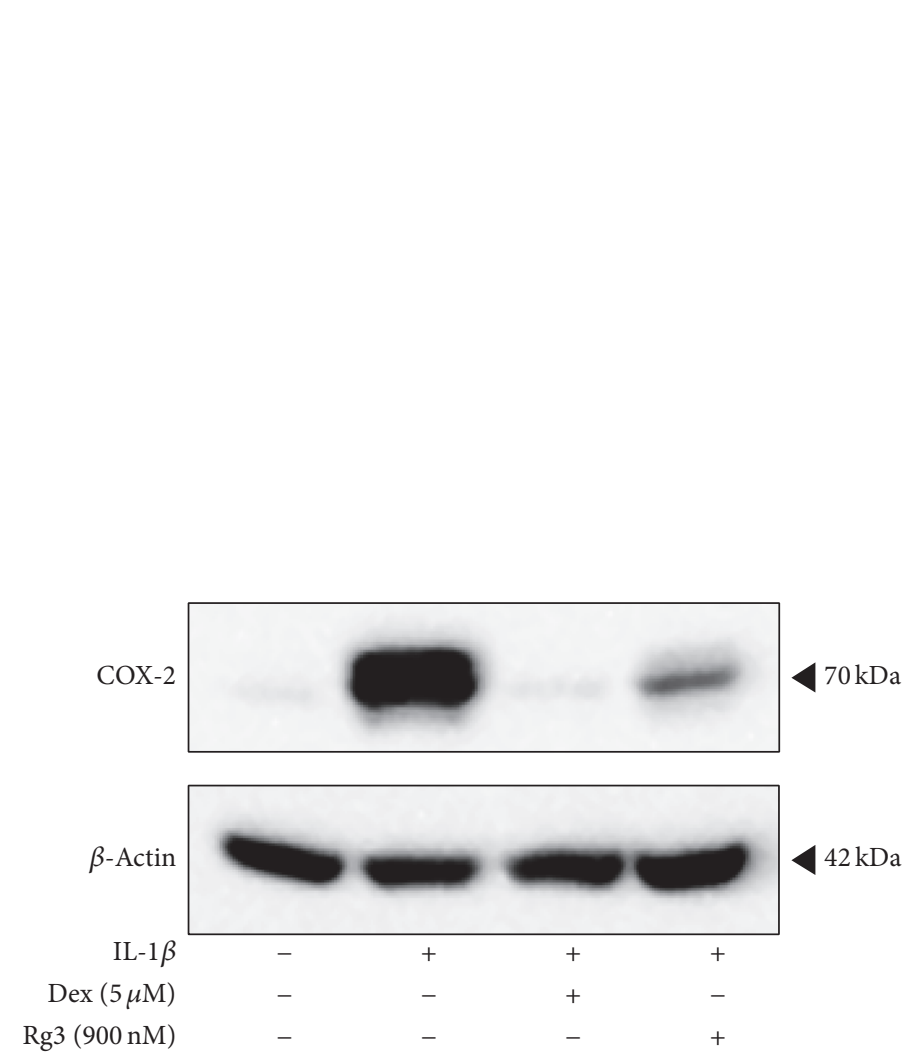

(a)

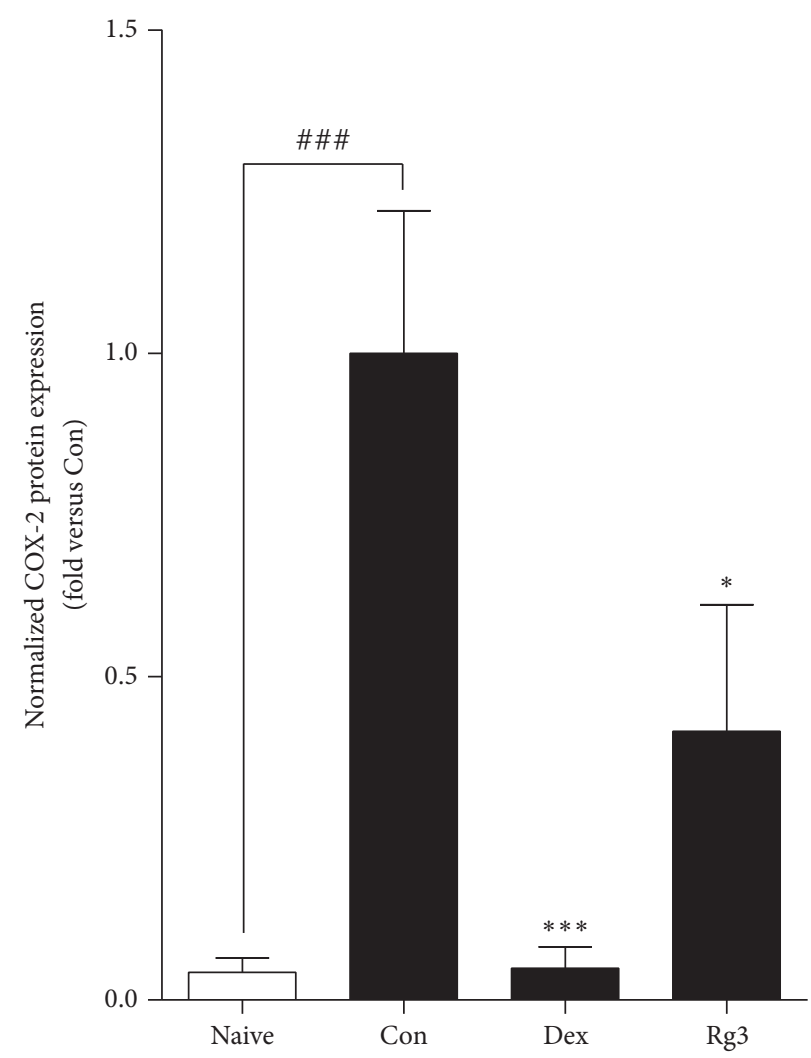

(b)

FIgURE 3: Inhibited IL-1 $\beta$-stimulated COX-2 expression by Rg3 in inflamed A549 cells. (a) The western blot results in representative three separate experiments. (b) COX-2 expression level normalized with $\beta$-actin was measured by densitometry analysis and represented as bar charts. Statistical significance was determined by unpaired $t$ test (one-tail) compared to Con. Values are means \pm SEM. ${ }^{\# \# \#} P<0.001$; ${ }^{*} P<$ $0.05 ;{ }^{* * *} P<0.001$. Naive: normal condition; Con: IL-1 $\beta$ treated A549 cells.

\subsection{Effects of Rg3 on NF- $\kappa B$ Activation in Human Asthmatic} Airway Epithelial Tissues. From the inhibitory effect of Rg3 on NF- $\kappa$ B activity in the inflamed airway epithelial cells, we anticipated that Rg3 may also inhibit NF- $\kappa$ B activation in human asthmatic airway epithelial tissues. The NF- $\kappa$ B activation was analyzed by a western blot analysis to evaluate the effect of Rg3 treatment on the tissues (Figure 4(a)). Human asthmatic airway epithelial tissue was treated with saline, $1 \mu \mathrm{M}$ of Dex, and $50 \mu \mathrm{M}$ of Rg3. We observed that there was a trend toward decreased phospho-NF- $\kappa$ B p65/total NF- $\kappa$ B p65 densitometry in the tissue treated with Rg3 (Figure 4(b)). The treatment of $\mathrm{Rg} 3$ on human asthmatic airway epithelial tissue showed a significant decrease in densitometry of pp65/p65; thereby inflammation may be reduced.

3.5. Rg3 Suppresses IL-1 $\beta$-Induced COX-2 Expression in Human Asthmatic Airway Epithelial Tissues. As we found the reducing effects of $\mathrm{Rg} 3$ on COX-2 expression in inflamed cells, we investigated the effects of $\mathrm{Rg} 3$ on the protein expression level of COX-2 in human asthmatic airway epithelial tissues. The protein expression level of COX-2 was also analyzed by a western blot analysis (Figure 5(a)). We found the significant inhibitory effects of Rg3 on COX-2 expression (Figure 5(b)).
3.6. Inhibition of NF- $\kappa B$-Mediated Proinflammatory Cytokines Secretion by Rg3 in Human Asthmatic Airway Epithelial Tissues. The cytokines/chemokines levels in media were determined by a multiplex assay, as described in Material and Methods. Specifically, IL-4, TNF- $\alpha$, and eotaxin concentration levels were significantly decreased in the tissues treated with $\operatorname{Rg} 3$ compared to saline-treated tissues (Figures $6(a)-6(c))$. Although there is no significant difference, the decreased tendencies of IL-6, IL-9, and IL-13 secretion levels were shown in Rg3-treated human asthmatic airway epithelial tissue compared to saline-treated tissue (Figures 6(d)$6(\mathrm{f})$ ). The data of that cytokine/chemokine associated with Th2-cells support our hypothesis that Rg3 may have an antiinflammatory effect by inhibiting NF- $\kappa$ B activation.

\section{Discussion}

The study was to determine whether $\operatorname{Rg} 3$ exerts antiinflammatory effects through the attenuation of the NF$\kappa \mathrm{B}$ signaling pathways in inflamed human airway epithelial cell and human asthmatic airway epithelial tissues and thereby whether Rg3 affects NF- $\kappa \mathrm{B}$-mediated proinflammatory cytokines in human asthmatic airway epithelial tissues. Once considered to largely act as a barrier function in the 

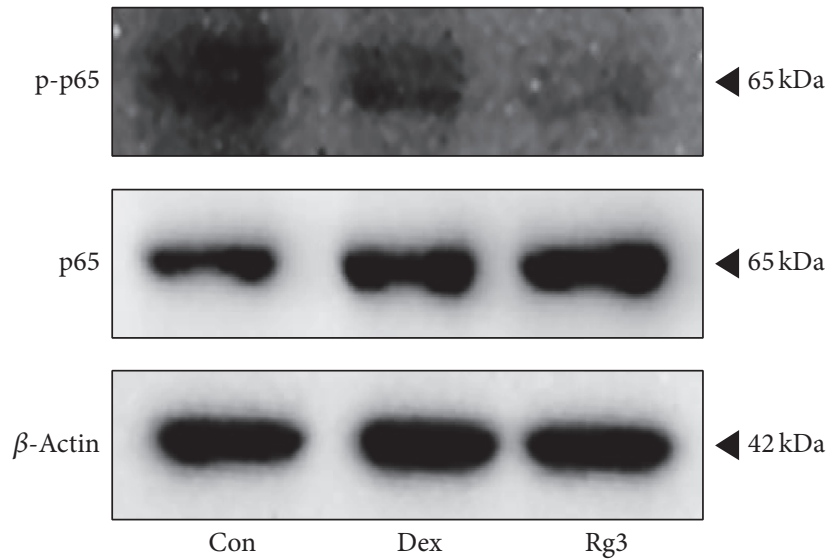

(a)

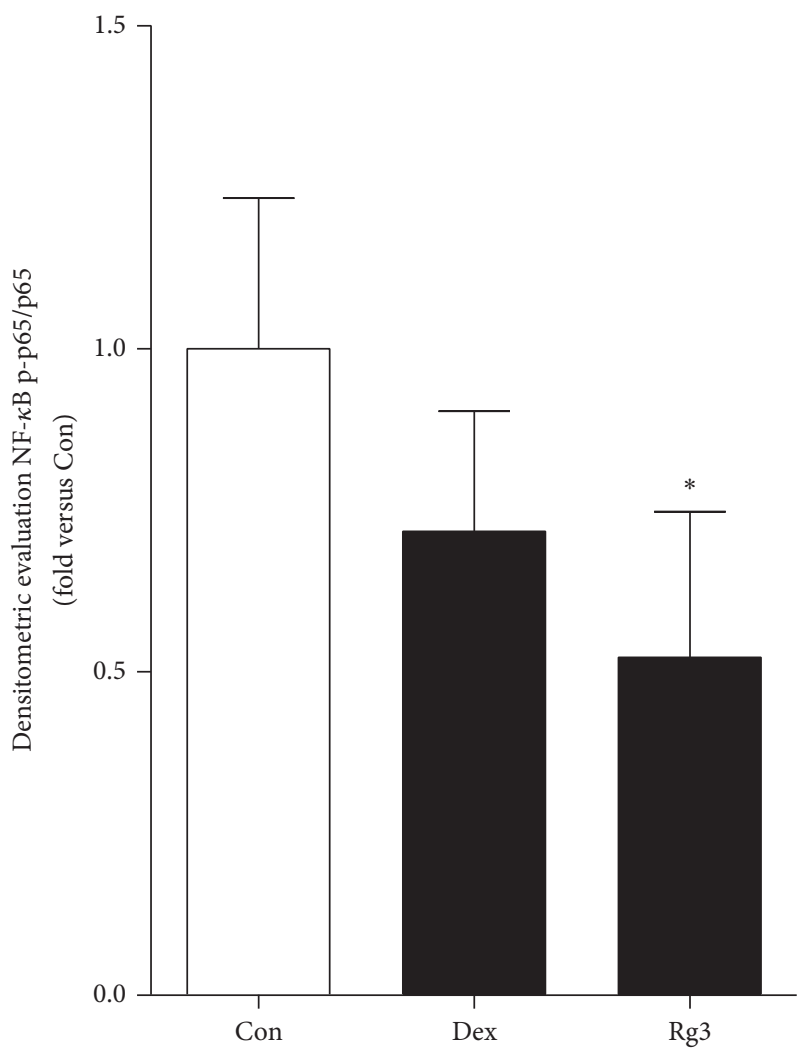

(b)

FIGURE 4: Suppressed NF- $\kappa$ B activation by Rg3 in human asthmatic airway epithelial tissues. (a) Human asthmatic lung tissue was treated with Dex for positive control or Rg3, and whole tissue lysates were prepared and then subjected to western blot analysis with anti-NF- $\kappa \mathrm{B}$ phospho-p65 or anti-NF- $\kappa$ B p 65 antibodies. Anti- $\beta$-actin antibody was used as an internal control. (b) Ratio of phospho-p65/p65 expression was measured by Image J program and represented as bar charts. Statistical significance was determined by unpaired $t$ test (one-tail) compared to Con (only PBS-treated asthmatic lung tissue). Values are means $\pm \mathrm{SEM} ;{ }^{*} P<0.05$.

lung, airway epithelium has been widely recognized for its immunomodulatory capabilities. Finally, there was the evaluation of the suppression of IL- $1 \beta$-induced inflammation by Rg3 in human airway epithelial cell. We conclusively demonstrated that Rg3 inhibited IL-1 $\beta$-induced NF- $\kappa$ B activation in human airway epithelial cell and also Rg3 suppressed NF- $\kappa \mathrm{B}$ activity in human asthmatic airway epithelial tissues and, as a result, $\mathrm{Rg} 3$ downregulated the expression of NF- $\kappa \mathrm{B}$-mediated gene products such as COX-2, IL-4, TNF- $\alpha$, and eotaxin.

$\mathrm{NF}-\kappa \mathrm{B}$, a protein complex, acts as a major player in the pathogenesis of inflammation regulating the expressions of multiple genes including iNOS, COX-2, and cytokines $[25,26]$. A study has reported that upregulated NF- $\kappa \mathrm{B}$ activity relates to asthmatic inflammation in human and animal lung tissues [50]. Thus, we evaluated the suppression effect of Rg3 on IL-1 $\beta$-stimulated NF- $\kappa$ B activity in human airway epithelial cell (Figure 2). The next step was whether Rg3 also blocked the NF- $\kappa$ B activity and we investigated proinflammatory cytokines secretion in human asthmatic airway epithelial tissues using western blotting analysis and multiplex assay, respectively (Figures 4 and 6).

We confirmed the reduction of NF- $\kappa \mathrm{B}$ expression by Rg3 in both inflamed A549 cells and human asthmatic airway epithelial tissues (Figures 2 and 4). We also confirmed that Rg3 inhibited the COX-2 expression, known as the downstream of NF- $\kappa \mathrm{B}$ activity. COX-2 is an enzyme that makes prostaglandins $\mathrm{E}_{2}\left(\mathrm{PGE}_{2}\right)$, which leads to inflammation and pain [51]. COX-2, identified in epithelial cells, macrophages, fibroblasts, smooth muscle cells, and mast cells, has important roles in immunity, renal physiology, neurotransmission, bone reabsorption, and pancreatic secretion [52, 53]. At first we found out the upregulated expression level of COX-2 by $10 \mathrm{ng} / \mathrm{ml}$ of IL-1 $\beta$ treatment in human airway epithelial cell. And the high expression level of COX-2 appeared in human asthmatic airway epithelial tissues. We confirmed that IL-1 $\beta$ stimulated COX-2 expression level was significantly reduced by Rg3 in human airway epithelial cell (Figure 3) and in human asthmatic airway epithelial tissues was also confirmed (Figure 5). As mentioned above, the reduction of COX-2 expression by Rg3 through inhibiting NF- $\kappa$ B activity leads to inhibition of the production of $\mathrm{PGE}_{2}$.

Many studies reported that cytokines and chemokines are involved in the pathophysiology of asthma $[9,19]$. The presence of IL- 4 induces the naïve T cell to Th2 cell and then the differentiated Th2 cells regulated cytokines. Among these cytokines, IL-1, IL- 6 , and TNF- $\alpha$ are considered to be 


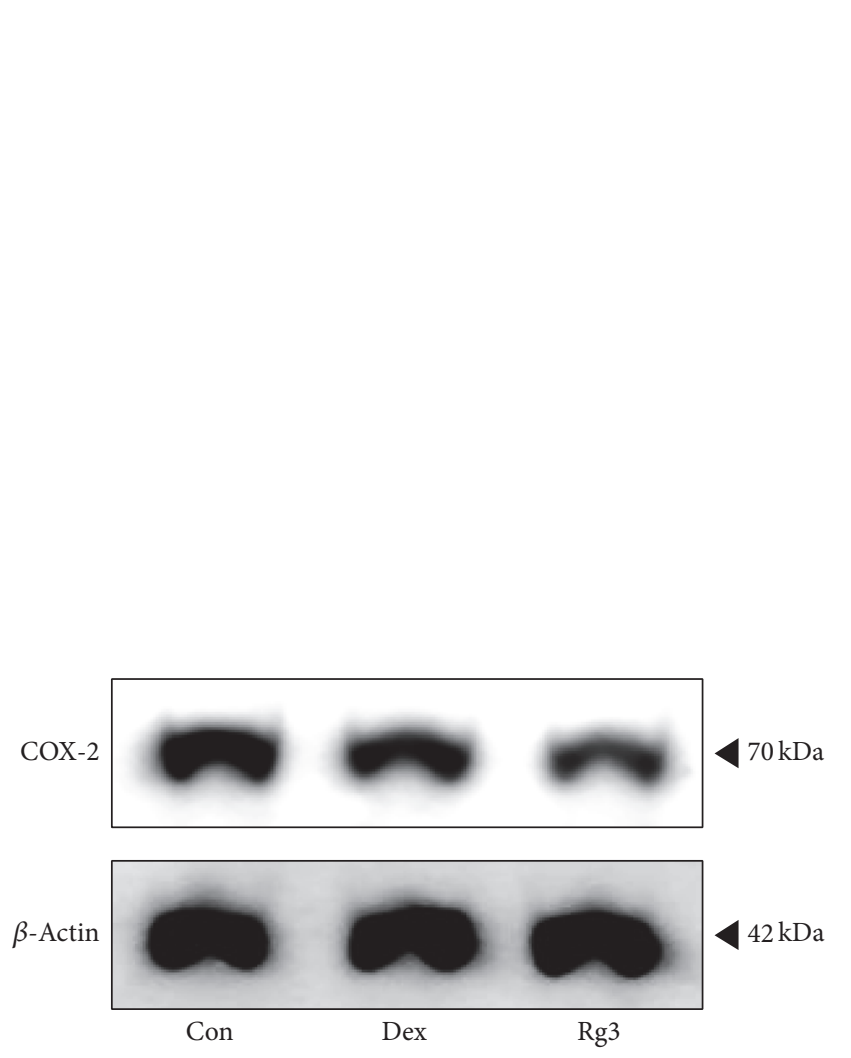

(a)

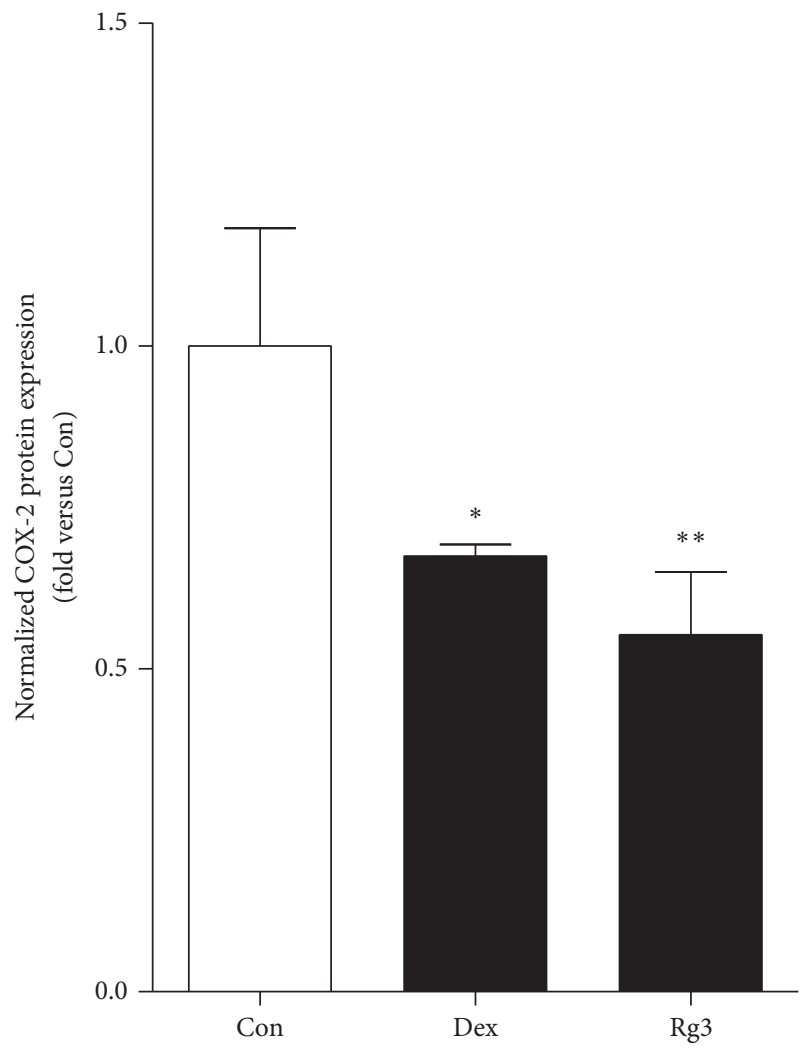

(b)

FIGURE 5: Effect of Rg3 on COX-2 protein inhibition in human asthmatic airway epithelial tissues. (a) Human asthmatic lung tissue was treated with Dex for positive control or Rg3, and whole tissue lysates were prepared and then subjected to western blot analysis with anti-COX-2 antibodies. Anti- $\beta$-actin antibody was used as an internal control. The blots were normalized by $\beta$-actin expression levels and compared to the saline-treated tissue. (b) Normalized COX-2 expression was measured by Image J program and represented as bar charts. Statistical significance was determined by unpaired $t$ test (one-tail) compared to Con (only PBS-treated asthmatic lung tissue). Values are means \pm SEM; ${ }^{*} P<0.05 ;{ }^{* *} P<0.01$.

involved in various inflammatory diseases including asthma and chronic pulmonary disease (COPD) [54]. As aforementioned, IL-4 encourages the naïve T cell to differentiate Th2 cell; thereby it regulates allergic inflammation. In addition, IL-4 induces IgE synthesis in the pathogenesis of asthma. IL-5 induces eosinophilic inflammation. IL-9 stimulates cell proliferation and regulates apoptosis. IL-13 has similar role as IL-4 including IgE synthesis [16, 17]. When IL-4 and IL13 are highly expressed, this state leads mucus hypersecretion and eosinophil infiltration to the airway tissues [55]. TNF- $\alpha$ is involved in systemic inflammation and plays an important role in endotoxemia. Increased TNF- $\alpha$ production levels improve the procoagulant activity of vascular endothelial cells, initiate macrophages, and increase adherent molecule expression, thus it enhances neutrophil infiltration [56]. In addition, TNF- $\alpha$ induces the $\mathrm{PGE}_{2}$ production via activating COX-2. Eotaxin is a chemokine subfamily of eosinophil chemotactic protein. It is involved in immune reaction in human and animal body [10]. In this study, we observed that Rg3 significantly reduced the secretion of IL-4, TNF$\alpha$, and eotaxin in human asthmatic airway epithelial tissues through inhibiting NF- $\kappa \mathrm{B}$ activity. Even though the significant reduction was not determined, there were trends toward decrease in the secretion of IL-6, IL-9, and IL-13 (Figure 6). The results from reduced cytokines secretion by $\mathrm{Rg} 3$ demonstrate that $\mathrm{Rg} 3$ may regulate the synthesis of IgE and the differentiation of naivve $T$ cell to $T_{h} 2$ cell through blocking IL-4 secretion and the eosinophil responses via inhibitory effect on eotaxin secretion. In addition, Rg3 also may suppress the $\mathrm{PGE}_{2}$ production via blocking TNF$\alpha$ secretion; thereby inflammation, fever, and pain followed by $\mathrm{PGE}_{2}$ production may decrease.

Due to the minimized side effects and excellent antiinflammatory effects of traditional Korean medicines, they are good options for treatment of asthmatic airway disease. Red ginseng has been widely applied as a Korean medicine in clinical prescription and has been used traditionally in oriental countries to improve health $[57,58]$. Ginsenosides are the major components of RG and more than 40 ginsenosides in RG were identified [40]. Rg3 is one of major components of RG [46]. Many studies have been reporting that Rg3 exhibits in vitro and in vivo anticarcinogenic and antimetastatic effects and also Rg3 exerted inhibitory effect on proliferation, capillary tube formation, and invasion of human umbilical vein endothelial cells (HUVEC) [59-61]. In addition, Rg3 has anti-inflammatory effects by inhibiting 


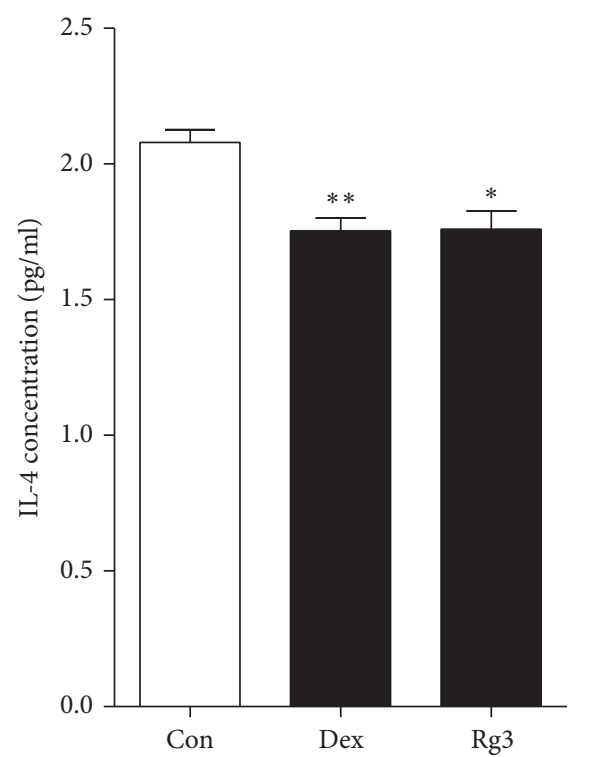

(a)

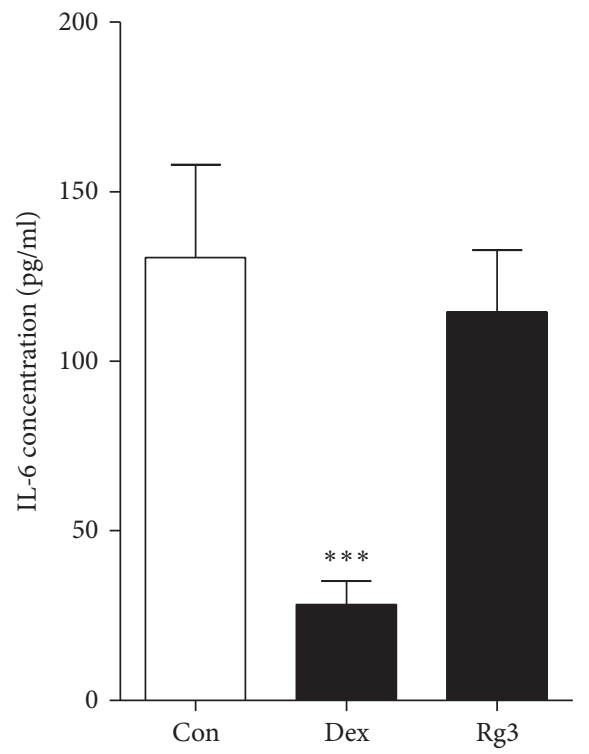

(d)

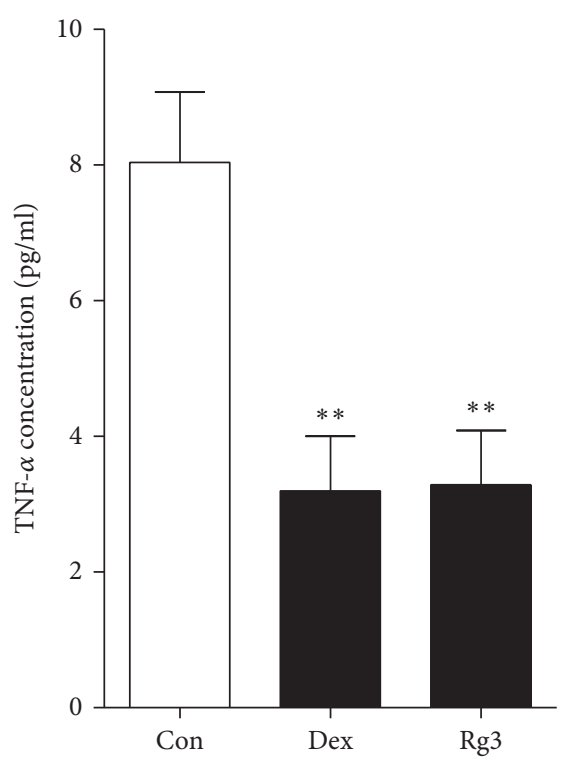

(b)

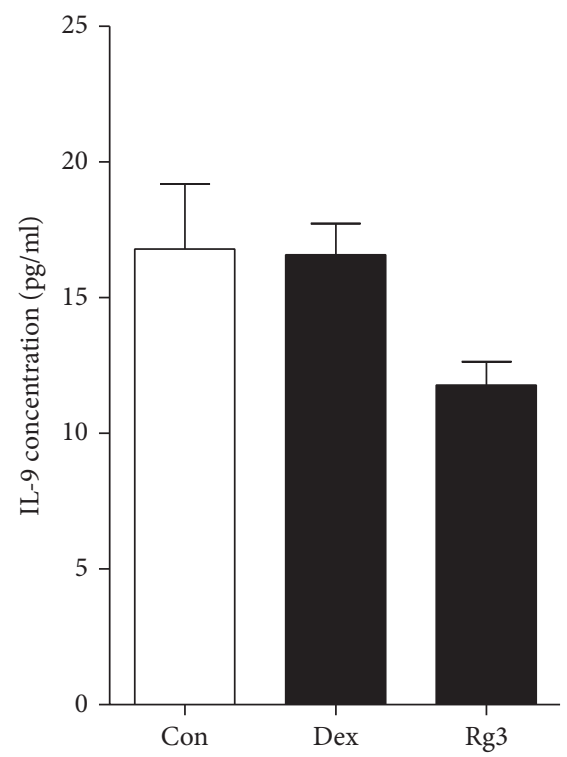

(e)

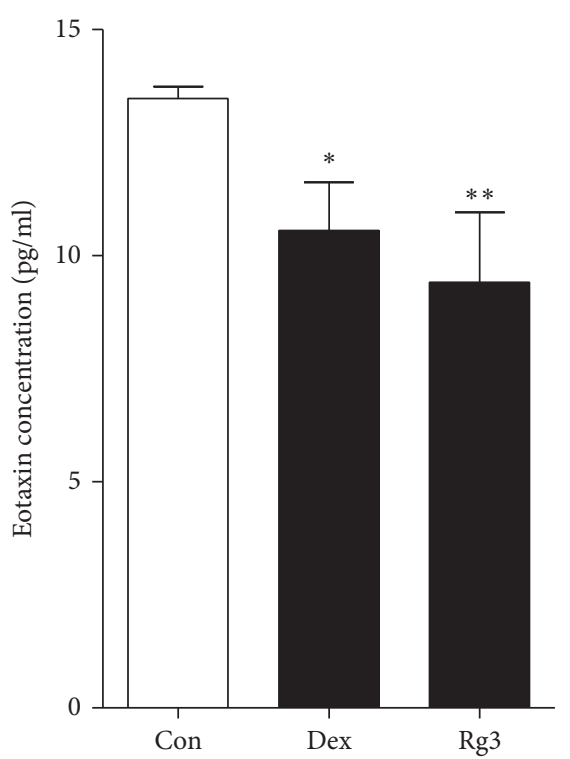

(c)

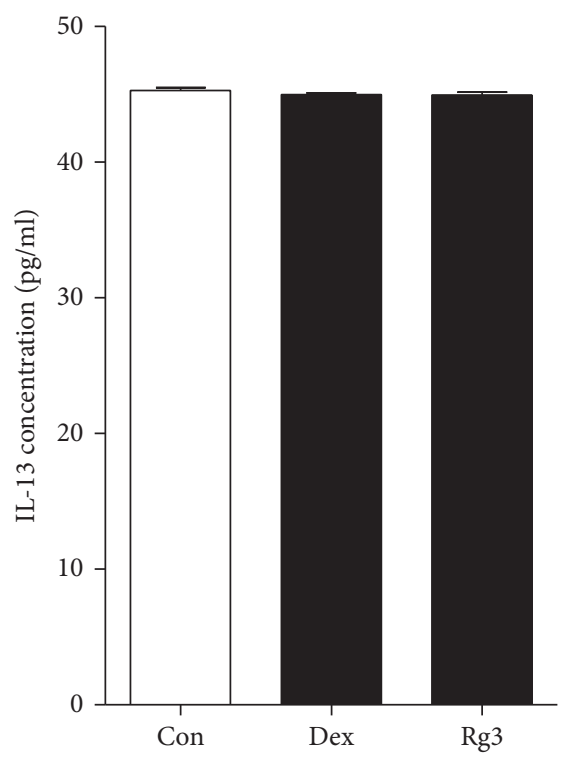

(f)

Figure 6: Anti-inflammatory effect of Rg3 on NF- $\kappa$ B-mediated proinflammatory cytokine/chemokine levels in human asthmatic airway epithelial tissues. Rg3 suppresses NF- $\kappa$ B-mediated proinflammatory cytokines IL- 4 , TNF- $\alpha$, and eotaxin secretion (a-c). IL-6, IL-9, and IL-13 had no statistical significance (d-f). Statistical significance was determined by unpaired $t$ test (one-tailed) compared to Con (only PBS-treated asthmatic lung tissue), and the values are means \pm SEM; ${ }^{*} P<0.05 ;{ }^{* *} P<0.01,{ }^{* * *} P<0.001$.

COX-2, iNOS expression, and proinflammatory cytokines production in LPS-induced cells $[47,48]$.

\section{Conclusion}

In conclusion, our data suggested that $\mathrm{Rg} 3$ regulates the inflammation reaction in the airways via inhibiting NF- $\kappa \mathrm{B}$ activity, an important role in inflammation due to its stimulus effect on the transcription of various proinflammatory gene, in IL-1 $\beta$-induced inflamed human airway epithelial cell and human asthmatic airway epithelial tissues. Thus COX-2 expression and the secretion NF- $\kappa \mathrm{B}$-mediated proinflammatory cytokines including IL-4, TNF- $\alpha$, and eotaxin were significantly reduced in human asthmatic airway epithelial tissues. Even though there was no significant reduction, the decrease tendency was demonstrated in the secretion of IL6, IL-9, and IL-13. This study demonstrates the inhibitory mechanism of ginsenoside $\mathrm{Rg} 3$ through the attenuation of NF- $\kappa \mathrm{B}$ activity in inflammation induced human airway epithelial cell and human asthmatic airway epithelial tissues. Thereby, Rg3 may be qualified as a potential remedial agent for asthma by inhibiting NF- $\kappa \mathrm{B}$ activation. 


\section{Competing Interests}

The authors declare that there is no conflict of interests regarding the publication of this paper.

\section{Authors' Contributions}

In-Seung Lee and InJoon Uh are co-first authors.

\section{Acknowledgments}

This research was supported by a grant from the Korea Health Technology R\&D Project through the Korea Health Industry Development Institute (KHIDI), funded by the Ministry of Health \& Welfare, Republic of Korea (Grant no. HI13C22960000).

\section{References}

[1] R. F. Lemanske Jr. and W. W. Busse, "Asthma: clinical expression and molecular mechanisms," Journal of Allergy and Clinical Immunology, vol. 125, no. 2, supplement 2, pp. S95-S102, 2010.

[2] S. E. Wenzel, "Asthma phenotypes: the evolution from clinical to molecular approaches," Nature Medicine, vol. 18, no. 5, pp. 716-725, 2012.

[3] British Thoracic Society and Scottish Intercollegiate Guidelines Network, "British guideline on the management of asthma," Thorax, vol. 69, supplement 1, pp. 1-192, 2014.

[4] J. Lee, M. Jung, S. Barthwal, S. Lee, and S.-H. Lim, "MEMS gas preconcentrator filled with CNT foam for exhaled VOC gas detection," Biochip Journal, vol. 9, no. 1, pp. 44-49, 2015.

[5] R. L. Miller and S.-M. Ho, "Environmental epigenetics and asthma: current concepts and call for studies," American Journal of Respiratory and Critical Care Medicine, vol. 177, no. 6, pp. 567573, 2008.

[6] C. Ober and S. Hoffjan, "Asthma genetics 2006: the long and winding road to gene discovery," Genes and Immunity, vol. 7, no. 2, pp. 95-100, 2006.

[7] F. J. Kelly and J. C. Fussell, "Air pollution and airway disease," Clinical and Experimental Allergy, vol. 41, no. 8, pp. 1059-1071, 2011.

[8] D. P. Strachan, "The role of environmental factors in asthma," British Medical Bulletin, vol. 56, no. 4, pp. 865-882, 2000.

[9] C. K. Wong, C. Y. Ho, F. W. S. Ko et al., "Proinflammatory cytokines (IL-17, IL-6, IL-18 and IL-12) and Th cytokines (IFN- $\gamma$, IL-4, IL-10 and IL-13) in patients with allergic asthma," Clinical and Experimental Immunology, vol. 125, no. 2, pp. 177-183, 2001.

[10] S. M. Pope, N. Zimmermann, K. F. Stringer, M. L. Karow, and M. E. Rothenberg, "The eotaxin chemokines and CCR3 are fundamental regulators of allergen-induced pulmonary eosinophilia," The Journal of Immunology, vol. 175, no. 8, pp. 5341-5350, 2005.

[11] E. Sawicka, C. Zuany-Amorim, C. Manlius et al., "Inhibition of Th1- and Th2-mediated airway inflammation by the sphingosine 1-phosphate receptor agonist fty720," Journal of Immunology, vol. 171, no. 11, pp. 6206-6214, 2003.

[12] P. M. Matricardi, F. Rosmini, S. Riondino et al., "Exposure to foodborne and orofecal microbes versus airborne viruses in relation to atopy and allergic asthma: epidemiological study," British Medical Journal, vol. 320, no. 7232, pp. 412-417, 2000.
[13] K. Kim, J. Y. Park, I. Lee, K. J. Lim, W. S. Jung, and H. Jang, "Isolated protein of Astragalus membranaceus acts as an allergen by binding human immunoglobulin E on human sera," BioChip Journal, vol. 10, no. 2, pp. 95-102, 2016.

[14] M. A. Rank and J. T. C. Li, "Allergen immunotherapy," Mayo Clinic Proceedings, vol. 82, no. 9, pp. 1119-1123, 2007.

[15] M. R. Edwards, N. W. Bartlett, D. Clarke, M. Birrell, M. Belvisi, and S. L. Johnston, "Targeting the NF- $\kappa \mathrm{B}$ pathway in asthma and chronic obstructive pulmonary disease," Pharmacology and Therapeutics, vol. 121, no. 1, pp. 1-13, 2009.

[16] G. Grünig, M. Warnock, A. E. Wakil et al., "Requirement for IL13 independently of IL-4 in experimental asthma," Science, vol. 282, no. 5397, pp. 2261-2263, 1998.

[17] M. Wills-Karp, J. Luyimbazi, X. Xu et al., "Interleukin-13: central mediator of allergic asthma," Science, vol. 282, no. 5397, pp. 2258-2261, 1998.

[18] W. Fan, W. Wang, L. Zhang, L. Qi, and A. Liu, "Study on changes and mechanisms of cytokines for alloxan-induced hepatic injury by $\mathrm{Cr}^{3+}$-treatment in mice," Molecular \& Cellular Toxicology, vol. 12, no. 2, pp. 209-216, 2016.

[19] P. J. Barnes, "Th2 cytokines and asthma: an introduction," Respiratory Research, vol. 2, no. 2, pp. 64-65, 2001.

[20] S. J. Szabo, A. S. Dighe, U. Gubler, and K. M. Murphy, "Regulation of the interleukin (IL)-12R $\beta 2$ subunit expression in developing T helper 1 (Th1) and Th2 cells," The Journal of Experimental Medicine, vol. 185, no. 5, pp. 817-824, 1997.

[21] D. R. Lucey, M. Clerici, and G. M. Shearer, "Type 1 and type 2 cytokine dysregulation in human infectious, neoplastic, and inflammatory diseases," Clinical Microbiology Reviews, vol. 9, no. 4, pp. 532-562, 1996.

[22] P. Bradding, I. H. Feather, S. Wilson et al., "Immunolocalization of cytokines in the nasal mucosa of normal and perennial rhinitic subjects. The mast cell as a source of IL-4, IL-5, and IL-6 in human allergic mucosal inflammation," The Journal of Immunology, vol. 151, no. 7, pp. 3853-3865, 1993.

[23] G. Del Prete, M. De Carli, F. Almerigogna, M. G. Giudizi, R. Biagiotti, and S. Romagnani, "Human IL-10 is produced by both type 1 helper (Th1) and type 2 helper (Th2) T cell clones and inhibits their antigen-specific proliferation and cytokine production," Journal of Immunology, vol. 150, no. 2, pp. 353-360, 1993.

[24] G. Trinchieri, "Interleukin-12: a cytokine produced by antigenpresenting cells with immunoregulatory functions in the generation of T-helper cells type 1 and cytotoxic lymphocytes," Blood, vol. 84, no. 12, pp. 4008-4027, 1994.

[25] A. Livolsi, V. Busuttil, V. Imbert, R. T. Abraham, and J.-F. Peyron, "Tyrosine phosphorylation-dependent activation of NF- $\kappa$ B: requirement for p56 LCK and ZAP-70 protein tyrosine kinases," European Journal of Biochemistry, vol. 268, no. 5, pp. 1508-1515, 2001.

[26] A. S. Baldwin, "The NF- $\kappa$ B and $\mathrm{I} \kappa \mathrm{B}$ proteins: new discoveries and insights," Annual Review of Immunology, vol. 14, no. 1, pp. 649-681, 1996.

[27] J. Tao, D. Zhang, Y. Man, W. Wang, and Y. Bi, "Sodium ferulate inhibits high-fat diet-induced inflammatory factors expression in human umbilical vein endothelial cells," Molecular \& Cellular Toxicology, vol. 12, no. 2, pp. 117-123, 2016.

[28] S. S. Makarov, "NF- $\kappa$ B in rheumatoid arthritis: a pivotal regulator of inflammation, hyperplasia, and tissue destruction," Arthritis Research, vol. 3, no. 4, pp. 200-206, 2001. 
[29] Y. M. W. Janssen-Heininger, M. E. Poynter, S. W. Aesif et al., "Nuclear factor $\kappa \mathrm{B}$, airway epithelium, and asthma avenues for redox control," Proceedings of the American Thoracic Society, vol. 6, no. 3, pp. 249-255, 2009.

[30] R. Pawankar, S. Mori, C. Ozu, and S. Kimura, "Overview on the pathomechanisms of allergic rhinitis," Asia Pacific Allergy, vol. 1, no. 3, pp. 157-167, 2011.

[31] L. Yang, L. Cohn, D.-H. Zhang, R. Homer, A. Ray, and P. Ray, "Essential role of nuclear factor $\kappa \mathrm{B}$ in the induction of eosinophilia in allergic airway inflammation," Journal of Experimental Medicine, vol. 188, no. 9, pp. 1739-1750, 1998.

[32] C. E. Donovan, D. A. Mark, H. Z. He et al., "NF- $\kappa$ B/Rel transcription factors: c-Rel promotes airway hyperresponsiveness and allergic pulmonary inflammation," Journal of Immunology, vol. 163, no. 12, pp. 6827-6833, 1999.

[33] X. M. Li, "Complementary and alternative medicine in pediatric allergic disorders," Current Opinion in Allergy and Clinical Immunology, vol. 9, no. 2, pp. 161-167, 2009.

[34] J. K. Chen and T. T. Chen, Chinese Herbal Formulas and Applications: Pharmacological Effects \& Clinical Research, Art of Medicine Press, City of Industry, Calif, USA, 2009.

[35] C. A. Slader, H. K. Reddel, C. R. Jenkins, C. L. Armour, and S. Z. Bosnic-Anticevich, "Complementary and alternative medicine use in asthma: who is using what?" Respirology, vol. 11, no. 4, pp. 373-387, 2006.

[36] C.-E. Hong and S.-Y. Lyu, "Anti-inflammatory and antioxidative effects of Korean red ginseng extract in human keratinocytes," Immune Network, vol. 11, no. 1, pp. 42-49, 2011.

[37] M.-S. Hyun, J.-M. Hur, Y.-S. Shin, B.-J. Song, Y.-J. Mun, and W.H. Woo, "Comparison study of white ginseng, red ginseng, and fermented red ginseng on the protective effect of LPS-induced inflammation in RAW 264.7 cells," Journal of Applied Biological Chemistry, vol. 52, no. 1, pp. 21-27, 2009.

[38] J. S. Lee, H. S. Choi, S. W. Kang et al., "Therapeutic effect of Korean red ginseng on inflammatory cytokines in rats with focal cerebral ischemia/reperfusion injury," The American Journal of Chinese Medicine, vol. 39, no. 1, pp. 83-94, 2011.

[39] T. Yu, M. H. Rhee, J. Lee et al., "Ginsenoside Rc from Korean red ginseng (Panax ginseng C.A. Meyer) attenuates inflammatory symptoms of gastritis, hepatitis and arthritis," The American Journal of Chinese Medicine, vol. 44, no. 3, pp. 595-615, 2016.

[40] K.-I. Samukawa, H. Yamashita, H. Matsuda, and M. Kubo, "Simultaneous analysis of saponins in Ginseng Radix by high performance liquid chromatography," Chemical and Pharmaceutical Bulletin, vol. 43, no. 1, pp. 137-141, 1995.

[41] Y. Cheng, L.-H. Shen, and J.-T. Zhang, "Anti-amnestic and antiaging effects of ginsenoside Rgl and Rbl and its mechanism of action," Acta Pharmacologica Sinica, vol. 26, no. 2, pp. 143-149, 2005.

[42] K. Sato, M. Mochizuki, I. Saiki, Y. C. Yoo, K.-I. Samukawa, and I. Azuma, "Inhibition of tumor angiogenesis and metastasis by a saponin of Panax ginseng, ginsenoside-Rb2," Biological and Pharmaceutical Bulletin, vol. 17, no. 5, pp. 635-639, 1994.

[43] M. Mochizuki, Y. C. Yoo, K. Matsuzawa et al., "Inhibitory effect of tumor metastasis in mice by saponins, ginsenoside-Rb2, 20(R)- and 20(S)-ginsenoside-Rg3, of Red ginseng," Biological and Pharmaceutical Bulletin, vol. 18, no. 9, pp. 1197-1202, 1995.

[44] E.-K. Park, M.-K. Choo, E.-J. Kim, M. J. Han, and D.-H. Kim, "Antiallergic activity of ginsenoside Rh2," Biological and Pharmaceutical Bulletin, vol. 26, no. 11, pp. 1581-1584, 2003.
[45] H. Zheng, Y. Jeong, J. Song, and G. E. Ji, “Oral administration of ginsenoside Rhl inhibits the development of atopic dermatitislike skin lesions induced by oxazolone in hairless mice," International Immunopharmacology, vol. 11, no. 4, pp. 511-518, 2011.

[46] S. N. Kim, Y. W. Ha, H. Shin, S. H. Son, S. J. Wu, and Y. S. Kim, "Simultaneous quantification of 14 ginsenosides in Panax ginseng C.A. Meyer (Korean red ginseng) by HPLC-ELSD and its application to quality control," Journal of Pharmaceutical and Biomedical Analysis, vol. 45, no. 1, pp. 164-170, 2007.

[47] B. Lee, B. Sur, J. Park et al., "Ginsenoside Rg3 alleviates lipopolysaccharide-induced learning and memory impairments by anti-inflammatory activity in rats," Biomolecules and Therapeutics, vol. 21, no. 5, pp. 381-390, 2013.

[48] K. S. Kang, H. Y. Kim, N. Yamabe, J. H. Park, and T. Yokozawa, "Preventive effect of 20(S)-ginsenoside $\mathrm{Rg}_{3}$ against lipopolysaccharide-induced hepatic and renal injury in rats," Free Radical Research, vol. 41, no. 10, pp. 1181-1188, 2007.

[49] H. T. Vo, J. Y. Cho, Y.-E. Choi, Y.-S. Choi, and Y.-H. Jeong, "Kinetic study for the optimization of ginsenoside Rg3 production by heat treatment of ginsenoside Rb1," Journal of Ginseng Research, vol. 39, no. 4, pp. 304-313, 2015.

[50] J. L. Ather, S. R. Hodgkins, Y. M. W. Janssen-Heininger, and M. E. Poynter, "Airway epithelial NF- $\kappa$ B activation promotes allergic sensitization to an innocuous inhaled antigen," American Journal of Respiratory Cell and Molecular Biology, vol. 44, no. 5, pp. 631-638, 2011.

[51] A. J. Wiemer, S. Hegde, J. E. Gumperz, and A. Huttenlocher, "A live imaging cell motility screen identifies prostaglandin $\mathrm{E}_{2}$ as a T cell stop signal antagonist," Journal of Immunology, vol. 187, no. 7, pp. 3663-3670, 2011.

[52] K. Seibert, Y. Zhang, K. Leahy et al., "Pharmacological and biochemical demonstration of the role of cyclooxygenase 2 in inflammation and pain," Proceedings of the National Academy of Sciences of the United States of America, vol. 91, no. 25, pp. 12013-12017, 1994.

[53] T. A. Samad, K. A. Moore, A. Sapirstein et al., "Interleukin$1 \beta$-mediated induction of Cox-2 in the CNS contributes to inflammatory pain hypersensitivity," Nature, vol. 410, no. 6827, pp. 471-475, 2001.

[54] S. T. Holgate, "Pathogenesis of asthma," Clinical and Experimental Allergy, vol. 38, no. 6, pp. 872-897, 2008.

[55] J. C. Kips, “Cytokines in asthma," The European Respiratory Journal. Supplement, vol. 34, pp. 24s-33s, 2001.

[56] K. J. Tracey, S. F. Lowry, B. Beutler, A. Cerami, J. D. Albert, and G. T. Shires, "Cachectin/tumor necrosis factor mediates changes of skeletal muscle plasma membrane potential," Journal of Experimental Medicine, vol. 164, no. 4, pp. 1368-1373, 1986.

[57] H. K. Choi, D. H. Seong, and K. H. Rha, "Clinical efficacy of Korean red ginseng for erectile dysfunction," International journal of impotence research, vol. 7, no. 3, pp. 181-186, 1995.

[58] S. H. Lee, W. S. Park, and M. H. Lim, "Clinical effects of Korean red ginseng on attention deficit hyperactivity disorder in children: an observational study," Journal of Ginseng Research, vol. 35, no. 2, pp. 226-234, 2011.

[59] P. Y. K. Yue, D. Y. L. Wong, P. K. Wu et al., “The angiosuppressive effects of 20(R)- ginsenoside $\mathrm{Rg}_{3}$," Biochemical Pharmacology, vol. 72, no. 4, pp. 437-445, 2006. 
[60] J.-K. Min, J.-H. Kim, Y.-L. Cho et al., "20(S)-Ginsenoside $\mathrm{Rg}_{3}$ prevents endothelial cell apoptosis via inhibition of a mitochondrial caspase pathway," Biochemical and Biophysical Research Communications, vol. 349, no. 3, pp. 987-994, 2006.

[61] S. Y. Lee, G. T. Kim, S. H. Roh et al., "Proteomic analysis of the anti-cancer effect of 20S-ginsenoside Rg3 in human colon cancer cell lines," Bioscience, Biotechnology and Biochemistry, vol. 73, no. 4, pp. 811-816, 2009. 


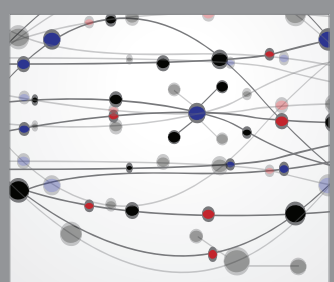

The Scientific World Journal
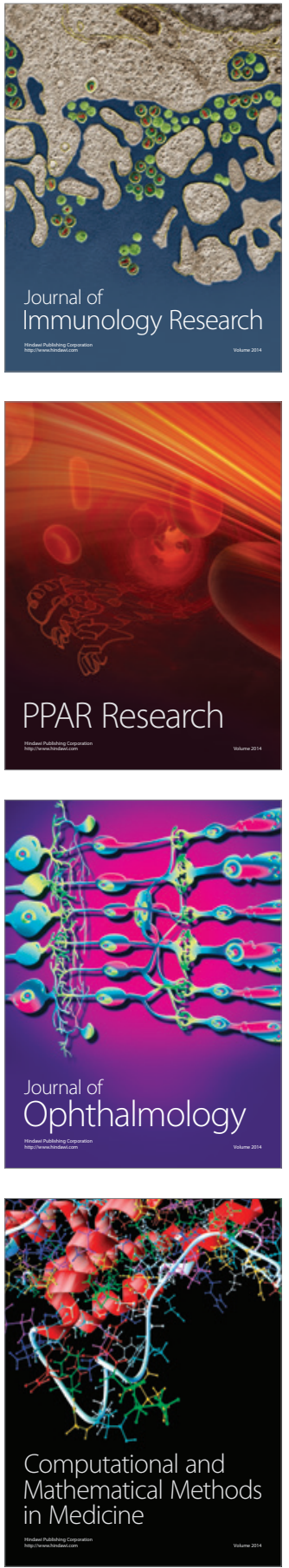

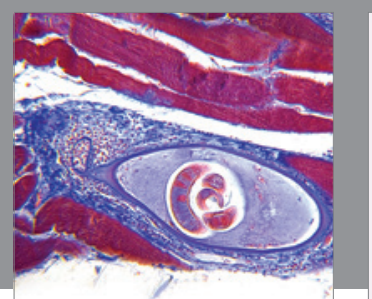

Gastroenterology Research and Practice

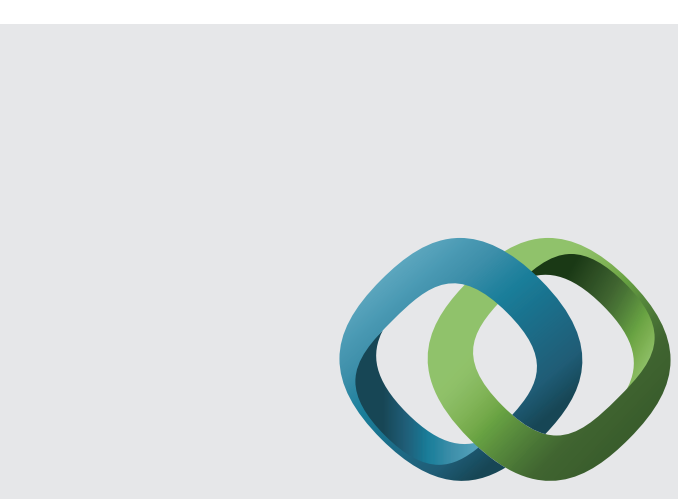

\section{Hindawi}

Submit your manuscripts at

http://www.hindawi.com
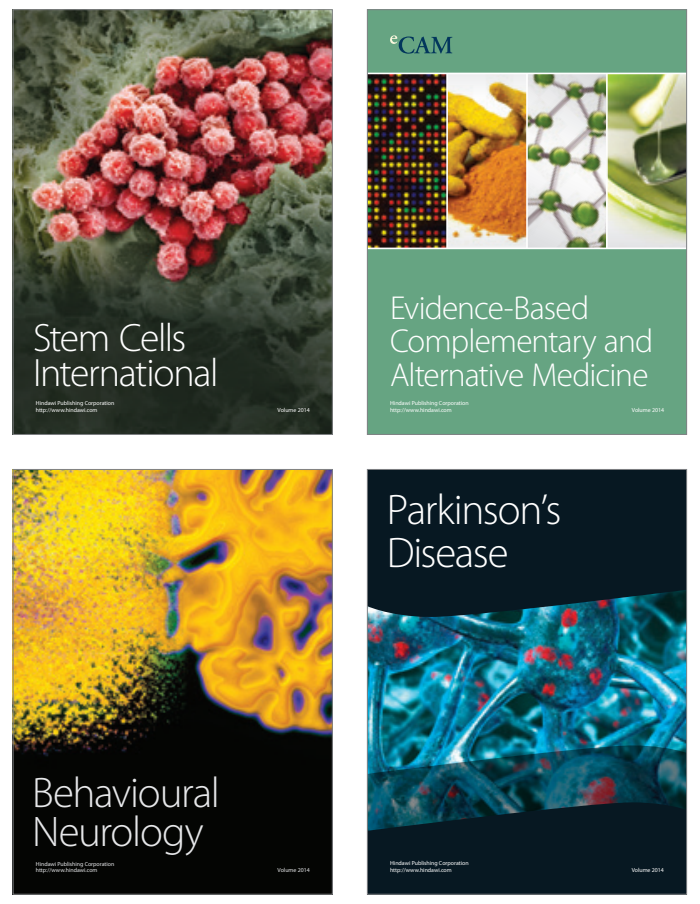
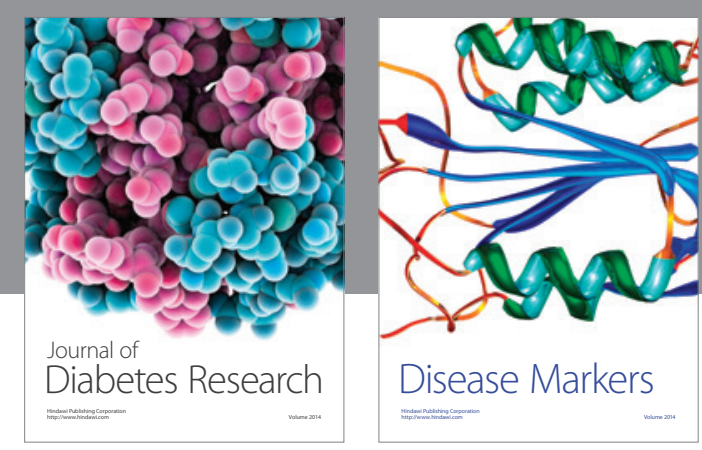

Disease Markers
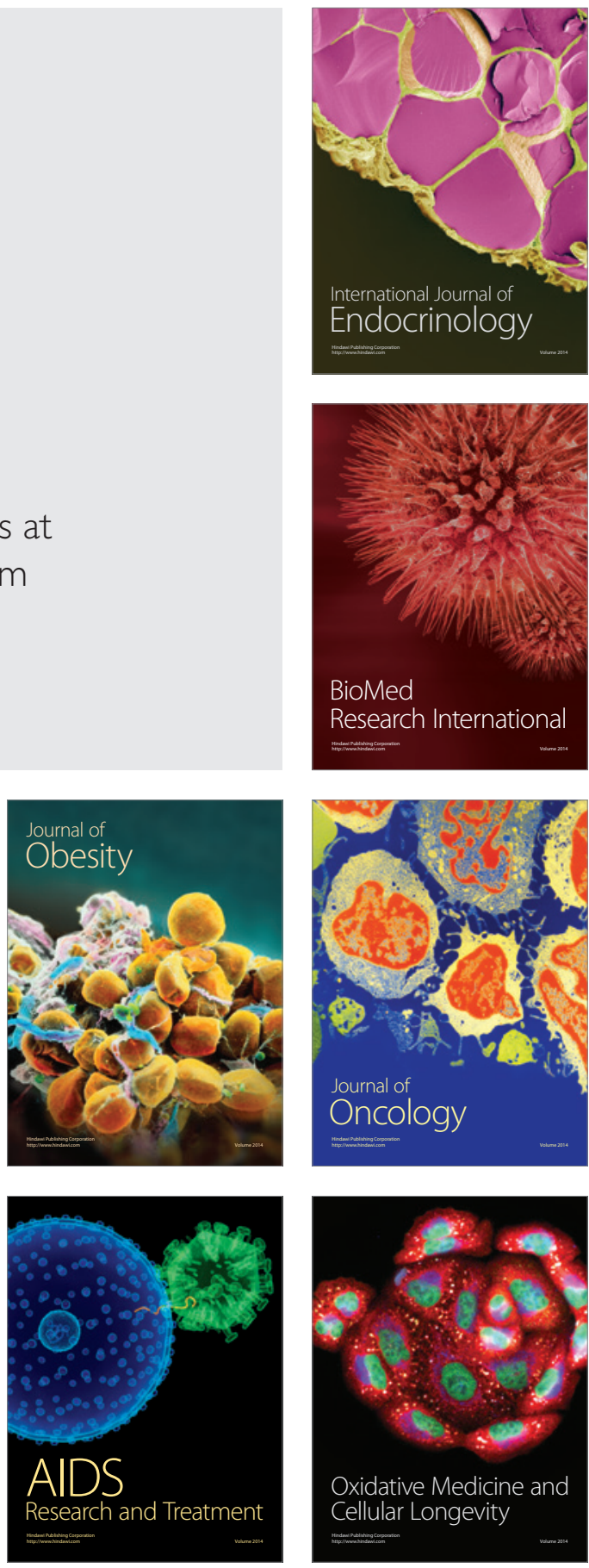